\title{
APLIKASI THERMOCHROMIC LIQUID CRYSTAL UNTUK MENGAMATI PERPINDAHAN KALOR PADA PERMUKAAN LOGAM
}

\author{
Risti Suryantari", Flaviana \\ Program Studi Fisika, Gedung 9 lantai 1, Fakultas Teknologi Informasi dan Sains, Universitas Katolik \\ Parahyangan, Bandung, 40141 \\ *email: ristisuryantari@unpar.ac.id
}

\section{ABSTRACT}

The purpose of this research was to observe the heat transfer on circular metal surface in contact with the surface of Thermochromic Liquid Crystal (TLC) R30C5W sheet, through the image on the surface of TLC during the heating process of metal. If the metal surface is in contact with the surface of TLC, the heat will move from the metal surface to TLC surface, and it is indicated by a color change on the surface of TLC. The original image is obtained in RGB is converted to hue image. The results showed, the value of mean hue increases by increasing temperature of metal surface. In addition, the value of hue along the center line of the circle image on the surface of TLC, fairly evenly distributed in the middle (inner circle) but diminishing the edges (right and left edges), which shows even further away from the edge of the metal surface, the thermal energy decreases because heat transfer occurs at the edges of the metal surface into the surrounding air.

Keywords: Thermochromic Liquid Crystal (TLC), hue, heat transfer.

\section{ABSTRAK}

Tujuan penelitian ini adalah untuk mengamati peristiwa perpindahan kalor pada area permukaan logam yang berbentuk lingkaran, yang bersentuhan dengan permukaan lembaran Thermochromic Liquid Crystal (TLC) R30C5W, melalui citra permukaan TLC selama proses pemanasan logam. Apabila permukaan logam tersebut bersentuhan dengan permukaan TLC, maka kalor akan berpindah dari permukaan logam ke permukaan $T L C$, dan ditunjukkan dengan terjadinya perubahan warna pada permukaan $T L C$. Citra asli yang diperoleh dalam format $R G B$ dikonversi menjadi citra hue. Hasil menunjukkan, seiring dengan meningkatnya temperatur permukaan logam, nilai mean hue semakin meningkat. Selain itu, nilai hue sepanjang garis tengah lingkaran pada permukaan $T L C$, cukup merata di bagian tengahnya (lingkaran dalam) namun semakin berkurang di tepinya (tepi kanan dan kiri), yang menunjukkan semakin jauh dari tepi permukaan logam maka energi kalornya semakin berkurang, karena terjadi perpindahan kalor pada tepi permukaan logam ke udara di sekitarnya.

Kata kunci: Thermochromic Liquid Crystal (TLC), hue, perpindahan kalor. 


\section{PENDAHULUAN}

Perubahan warna (color play) terjadi bila pada permukaan bahan Thermochromic Liquid Crystal (TLC) mengalami kontak dengan suatu benda, dalam rentang temperatur tertentu sesuai spesifikasi bahan. TLC memiliki karakteristik dengan memunculkan salah satu warna (merah, kuning, hijau, biru atau ungu) yang bergantung pada panjang gelombang yang dipantulkan pada temperatur tertentu. Keunikan bahan ini dapat dipikasikan dalam pengamatan berbagai fenomena termal ${ }^{[1]}$.

Color play pada TLC didefinisikan dengan spesifikasi warna tertentu, yaitu red start, midgreen, atau blue start. Sebagai contoh TLC R30C5W sheet menggambarkan TLC dengan red start pada $30{ }^{\circ} \mathrm{C}$, dan bandwidth $5{ }^{\circ} \mathrm{C}$. Rentang area temperatur dimana warna tidak muncul disebut clearing point, pada $T L C$ R30C5W clearing point terjadi setelah temperatur $35{ }^{\circ} \mathrm{C}$. Di luar rentang temperatur yang diijinkan oleh bahan tersebut, seluruh cahaya akan diserap, dan permukaan TLC akan tampak hitam ${ }^{[2]}$.

Bharara, 2007, melakukan penelitian menggunakan menggunakan TLC dan kamera digital dalam mengakuisisi data, untuk mengukur distribusi temperatur pada subyek penderita neuropati diabetic, dengan menggunakan analisis pencitraan berbasis citra hue. Kalibrasi dilakukan dengan menempatkan $T L C$ pada plat logam yang dapat diatur temperaturnya. Dari penelitiannya, diperoleh hubungan antara nilai hue citra permukaan TLC dengan temperatur plat logam yang menyentuhnya, ditunjukkan oleh Gambar $1^{[3]}$.

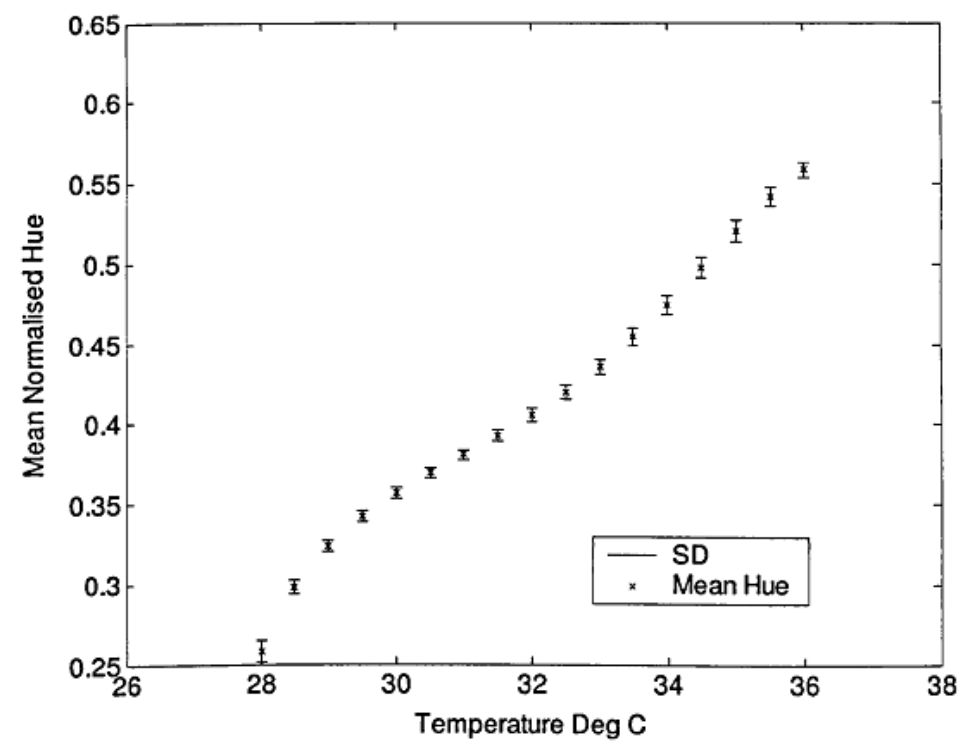

Gambar 1. Grafik hubungan antara nilai hue citra permukaan $T L C$ dengan temperatur plat logam ${ }^{[3]}$

Pada penelitian yang dilakukan oleh Suryantari dan Flaviana (2015), dilakukan pengambilan citra permukaan $T L C \mathrm{R} 25 \mathrm{C} 5 \mathrm{~W}$ dan $\mathrm{R} 30 \mathrm{C} 5 \mathrm{~W}$ yang mengalami kontak dengan permukaan labu erlenmayer yang diisi air pada temperatur tertentu, menggunakan scanner. Hasil citra diolah dengan metode pengolahan citra berbasis morfologi matematika. Hasil penelitian menunjukkan hubungan nilai hue terhadap temperatur, dimana kedua bahan TLC tersebut menunjukkan kecenderungan hubungan linearitas yang sama ${ }^{[4]}$. 
Penggunaan TLC untuk pengamatan berbagai fenomena termal perlu dikembangkan untuk memberikan informasi yang lebih luas mengenai peristiwa termal sekaligus mempelajari karakteristik material liquid crystal [5]. Oleh sebab itu pada penelitian ini, akan diaplikasikan TLC untuk mengamati peristiwa perpindahan kalor pada permukaan logam, dengan penjelasan secara kualitatif dan kuantitatif menggunakan metode pengolahan citra berbasis citra hue ${ }^{[6]}$, berdasarkan hasil penelitian-penelitian sebelumnya.

\section{METODE}

Dalam penelitian ini digunakan bahan utama berupa lembaran Thermochromic Liquid Crystal (TLC) ukuran $10 \times 10 \mathrm{~cm}$ dengan rentang temperatur $30-35{ }^{\circ} \mathrm{C}$ (dinamakan $T L C$ R30C5W). Scanner dengan resolusi optik 300 dpi dan bit depth 24-bit color dikoneksikan dengan komputer. Selama proses pengambilan data temperatur ruang diatur konstan pada $18{ }^{\circ} \mathrm{C}$. Lembaran $T L C$ diletakkan di atas permukaan scanner, kemudian di atas permukaan TLC diletakkan logam kuningan dengan diameter 0,035 m, massa $0,5 \mathrm{~kg}$, tinggi $0,068 \mathrm{~m}$, kalor jenis sebesar $377 \mathrm{~J} / \mathrm{kg} . \mathrm{K}$, dan konduktivitas termal $109 \mathrm{~J} / \mathrm{m} . \mathrm{s} . \mathrm{K}$. Pemanas celup dimasukkan ke dalam logam kuningan. Pemanas celup dihubungkan dengan sumber tegangan DC $12 \mathrm{~V}$ dan keluaran arus 5 A. Sensor temperatur diletakkan di dalam logam yang telah dihubungkan dengan pemanas celup, dan dikoneksikan dengan komputer. Nilai temperatur logam selama proses pemanasan akan muncul pada layar komputer. Set up alat dan bahan ditunjukkan oleh gambar 2 .

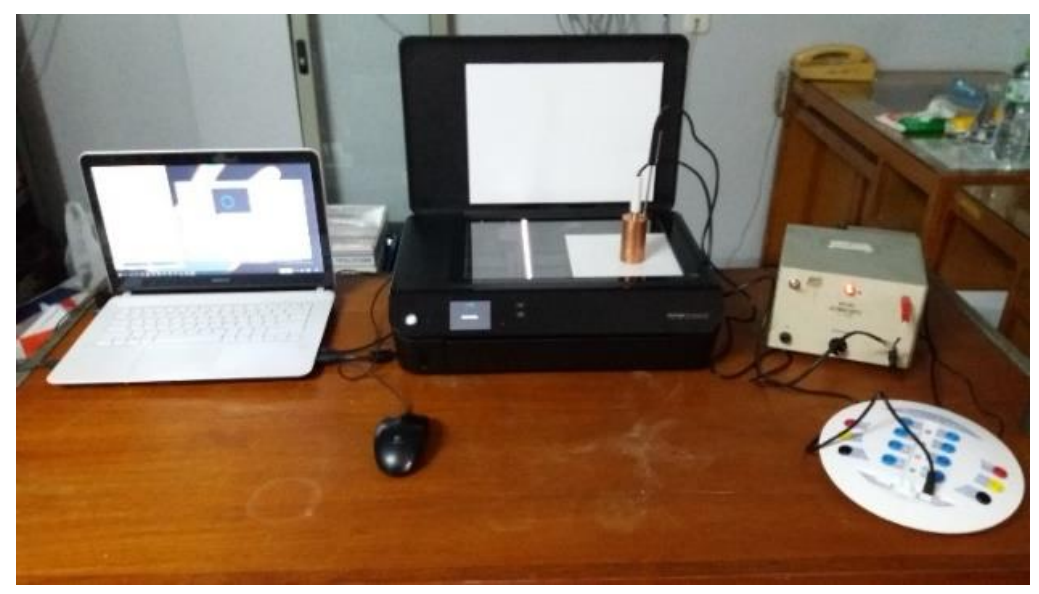

Gambar 2. (color online) Set up alat dan bahan

Citra pertama direkam dengan scanner tepat ketika sumber tegangan dinyalakan. Citra selanjutnya diambil setiap 30 detik hingga 300 detik (selama 5 menit proses pemanasan). Data temperatur keseluruhan (selama 5 menit tersebut) disimpan untuk menunjukkan nilai temperatur ketika citra direkam. Keseluruhan citra yang telah diperoleh kemudian diolah menggunakan MATLAB R2014a untuk kepentingan analisis. Tahapan pengolahan citra ditunjukkan oleh gambar 3. 

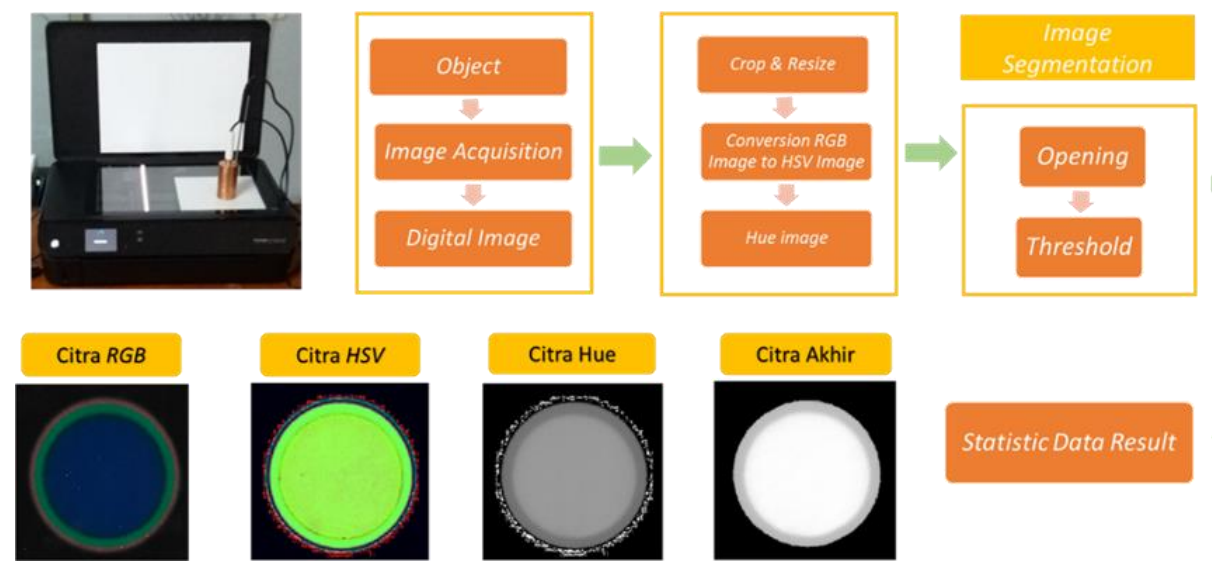

Statistic Data Result

Gambar 3. (color online) Tahapan pengolahan citra

\section{HASIL DAN PEMBAHASAN}

Selama proses perekaman citra permukaan TLC, temperatur di dalam logam dapat diukur menggunakan sensor temperatur setiap detik, selama proses pemanasan logam tersebut. Grafik kenaikan temperatur logam terhadap waktu ditunjukkan oleh gambar 4, dimana temperatur logam meningkat secara ekponensial dengan persamaan $y=23,23 e^{0.0023 x}$ dimana sumbu $y$ menunjukkan temperatur logam, dan sumbu $x$ adalah waktu pemanasan logam.

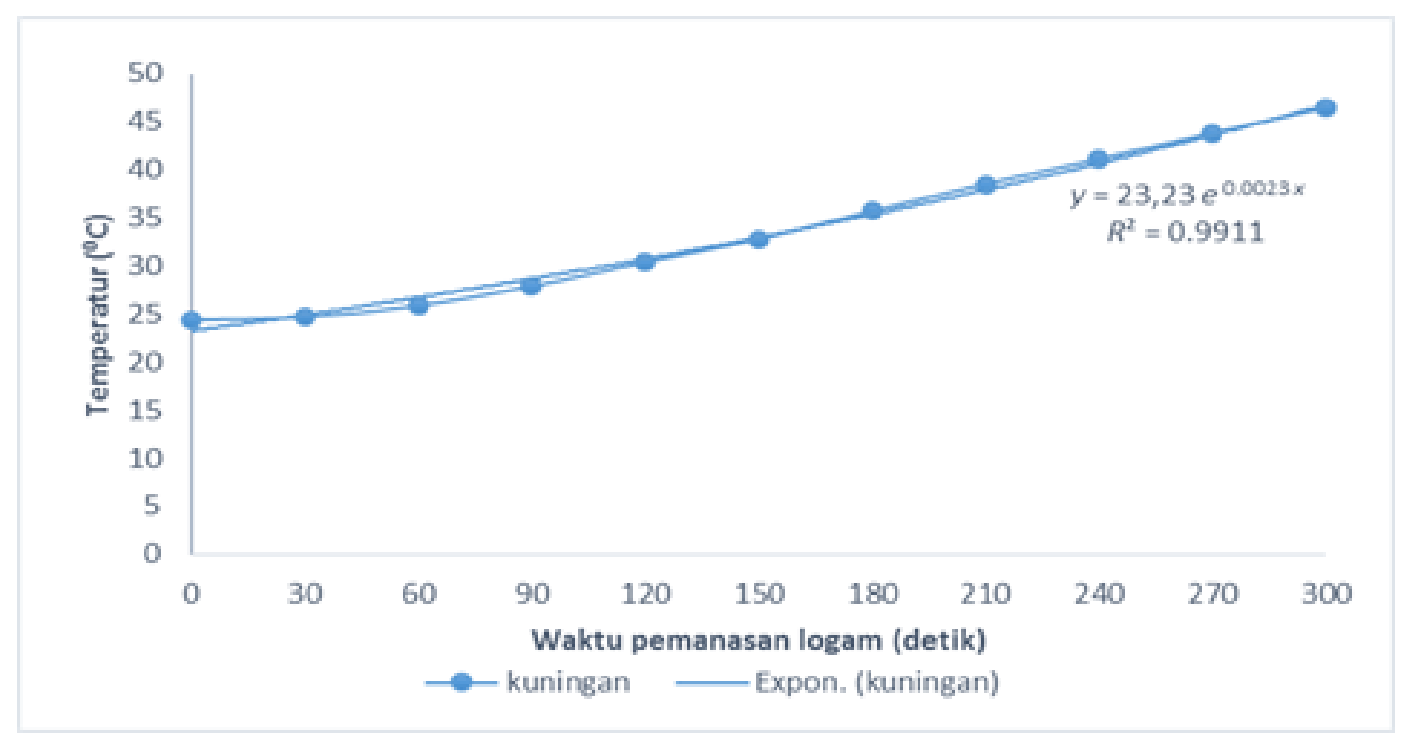

Gambar 4. (color online) Grafik kenaikan temperatur logam terhadap waktu pemanasan logam

Citra permukaan $T L C$ dalam format $R G B$ yang diperoleh ditunjukkan oleh gambar 5. Hasil citra pada gambar 5 menunjukkan $T L C$ R30C5W tidak memberikan respon hingga detik ke 90 (gambar 5d). Hal ini dikarenakan temperatur permukaan logam berada pada nilai kurang dari $30{ }^{\circ} \mathrm{C}$. Respon yang ditunjukkan dengan terbentuknya warna pada permukaan $T L C$ ditunjukkan mulai detik ke 120 (gambar 5e), dimana secara visual tampak permukaannya berwarna kemerahan. Citra selanjutnya menunjukkan perubahan warna yang semakin merata berupa kehijauan dan kebiruan, diikuti terbentuknya pola perubahan warna di sekeliling area yang tidak kontak langsung dengan permukaan logam kuningan. 


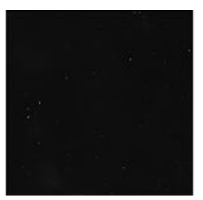

(a)

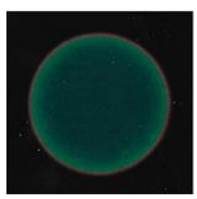

(g)

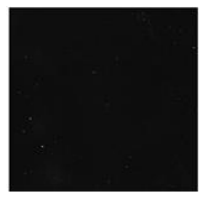

(b)

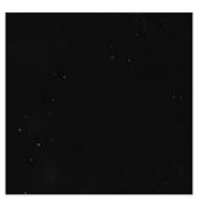

(c)

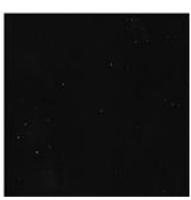

(d)

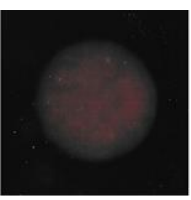

(e)

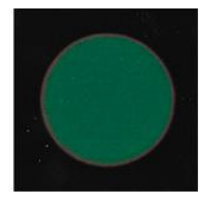

(f)

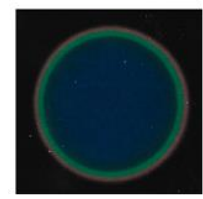

(h)

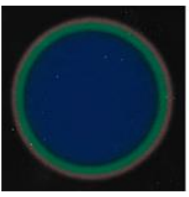

(i)

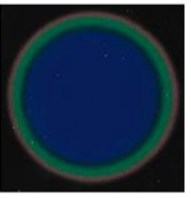

(j)

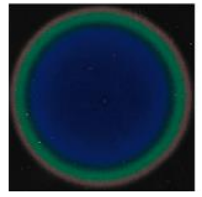

(k)

Gambar 5. (color online) Citra RGB permukaan TLC saat kontak dengan permukaan logam kuningan, pada detik ke (a) 0 (b) 30 (c) 60 (d) 90 (e) 120 (f) 150 (g) 180 (h) 210 (i) 240 (j) 270 (k) 300

Untuk dapat menganalisis citra sesara kuantitatif, citra tersebut diolah menjadi citra yang lebih sederhana. Pada pengolahan citra dipilih metode dengan mengubah citra $R G B$ menjadi $H S V$ dan mengambil komponen hue saja. Citra hue yang diperoleh perlu diolah kembali untuk mendapatkan kualitas yang lebih baik, misalnya untuk meratakan bagian tepi agar analisis dapat dibatasi hanya untuk daerah lingkaran yang distribusi nilai huenya cukup merata. Area paling tepi menunjukkan terjadinya perpindahan kalor ke lingkungan yang lebih besar. Hal ini dapat memberikan pengaruh cukup besar kepada perhitungan nilai hue rata-ratanya. Sementara area di sekeliling permukaan $T L C$ yang kontak langsung dengan permukaan logam tetap akan diambil, untuk menunjukkan pola perpindahan kalor pada permukaan logam ke lingkungan. Contoh hasil pengolahan citra ditunjukkan oleh gambar 6.

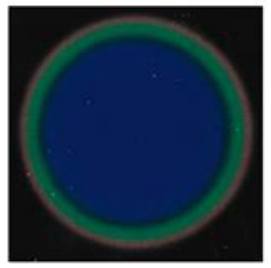

(a)

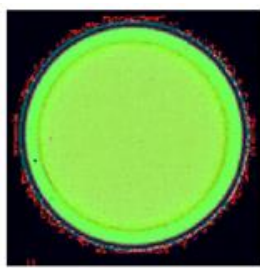

(b)

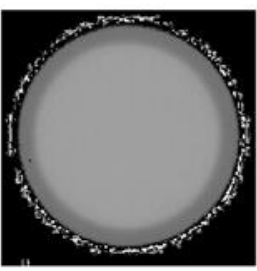

(c)

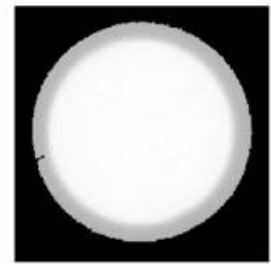

(d)

Gambar 6. (color online) Hasil pengolahan citra permukaan TLC saat kontak dengan permukaan logam kuningan, pada detik ke 270, (a) citra RGB (b) citra HSV (c) citra komponen hue (d) citra akhir

Pada citra akhir yang dihasilkan seperti pada gambar 6d, tampak dengan lebih jelas perbedaan kecerahan warna antara area sekitar pusat lingkaran dengan tepinya, sementara latar belakang berwarna hitam merupakan area permukaan TLC yang tidak memberikan respon terhadap temperatur permukaan logam karena temperaturnya berada kurang dari $30^{\circ} \mathrm{C}$. Warna terang yang ditunjukkan pada lingkaran bagian dalam cukup merata, demikian juga dengan sekelilingnya, sehingga tampak jelas batas antara kedua area tersebut. Luas lingkaran bagian dalam, sama dengan luasan permukaan logam yang mengenai permukaan $T L C$. 
Tabel 1. Data temperatur logam dan nilai mean hue citra permukaan TLC

\begin{tabular}{ccc}
\hline $\begin{array}{c}\text { Waktu pe ngambilan } \\
\text { citra (de tik) }\end{array}$ & Temperatur $\left({ }^{\circ} \mathbf{C}\right)$ & Nilai mean Hue \\
\hline $\mathbf{0}$ & 24,4 & 0 \\
\hline $\mathbf{3 0}$ & 24,7 & 0 \\
\hline $\mathbf{6 0}$ & 25,9 & 0 \\
\hline $\mathbf{9 0}$ & 27,9 & 0 \\
\hline $\mathbf{1 2 0}$ & 30,4 & 0,00772 \\
\hline $\mathbf{1 5 0}$ & 32,8 & 0,44032 \\
\hline $\mathbf{1 8 0}$ & 35,7 & 0,47587 \\
\hline $\mathbf{2 1 0}$ & 38,5 & 0,53579 \\
\hline $\mathbf{2 4 0}$ & 41,1 & 0,55682 \\
\hline $\mathbf{2 7 0}$ & 43,8 & 0,56428 \\
\hline $\mathbf{3 0 0}$ & 46,4 & 0,56536 \\
\hline
\end{tabular}

Berdasarkan citra akhir, dapat diperoleh nilai mean hue untuk untuk menunjukkan perbedaan setiap citra yang dihasilkan. Nilai hue berkisar antara 0-1. Bila nilai hue sama dengan nol menunjukkan citra berwarna hitam, dan bila nilai hue sama dengan 1 maka citra yang ditunjukkan adalah putih. Dalam perhitungan nilai mean hue, nilai nol tidak dimasukkan, karena merupakan latar belakang citra utama. Data nilai mean hue setiap citra dan nilai temperatur logam saat pengambilan citra tersebut ditunjukkan oleh tabel 1 . Hubungan antara nilai mean hue dengan kenaikan temperatur logam ditunjukkan oleh grafik gambar 7.

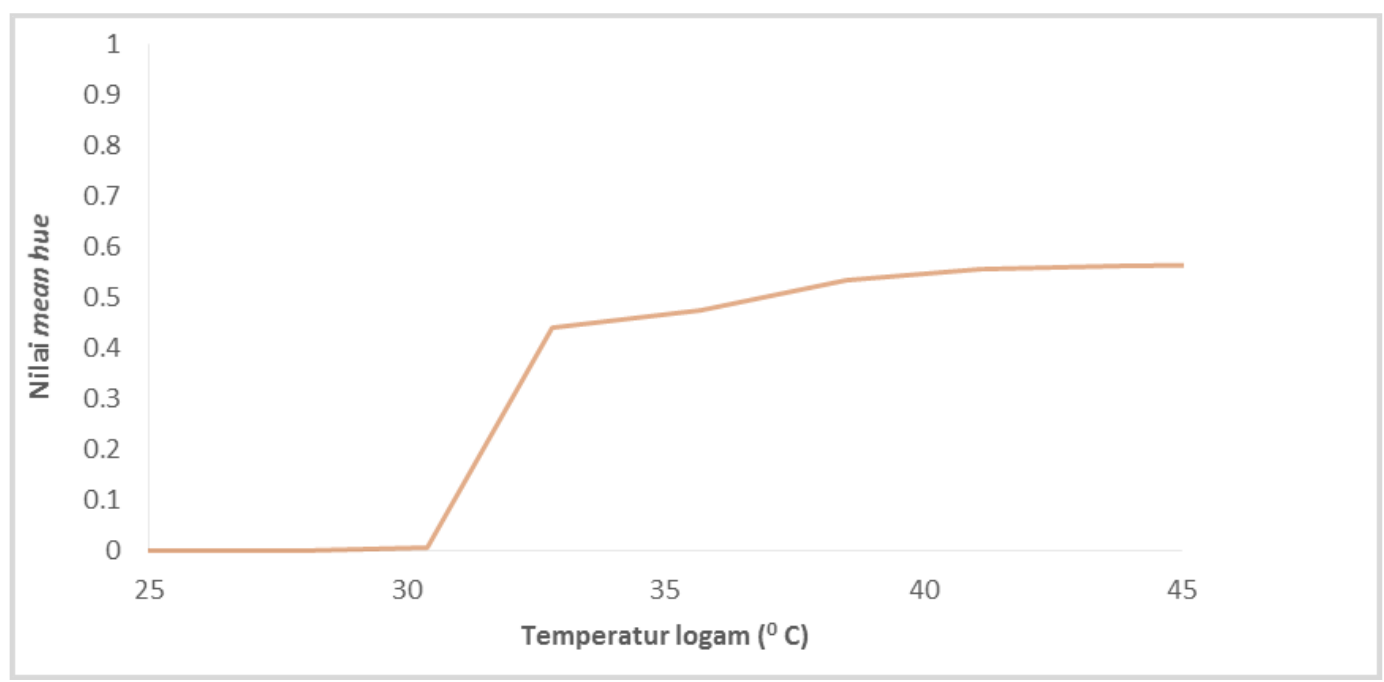

Gambar 7. (color online) Grafik hubungan nilai mean hue permukaan TLC terhadap kenaikan temperatur logam 
Berdasarkan grafik pada gambar 7, dapat ditunjukkan kecenderungan kenaikan nilai mean hue permukaan TLC seiring meningkatnya temperatur logam, hal ini sesuai pula dengan karakteristik $T L C$ seperti pada gambar 1 .

Bedasarkan gambar 6d, daerah tepi lingkaran yang lebih gelap menunjukkan temperatur permukaan TLC pada area tersebut lebih rendah daripada area lingkaran bagian dalam. Pada area lingkaran bagian dalam, tampak kecerahannya cukup merata, hal ini menunjukkan energi kalor yang dipindahkan dari permukaan logam ke permukaan TLC relatif sama. Namun semakin ke tepi, menunjukkan energi kalornya semakin berkurang. Artinya terjadi perpindahan kalor pada tepi permukaan logam ke udara di sekitarnya. Hal ini juga menunjukkan pertukaran kalor ke lingkungan lebih besar terjadi pada batas tepi permukaan logam ${ }^{[7]}$.

Molekul-molekul di dekat permukaan logam menerima kalor, dan mengubahnya menjadi energi kinetik bagi molekul udara tersebut, sehingga bergerak dengan lebih cepat sambil memindahkan sebagian energi kalornya ke molekul udara di sekitarnya secara konveksi ${ }^{[7]}$. Energi kalor yang dipindahkan dari permukaan logam ke udara di sekitarnya lebih kecil daripada energi kalor di dalam area permukaan logam. Semakin jauh dari permukaan logam maka energi kalornya semakin berkurang. Pola distribusi energi kalor pada permukaan logam dan di sekitar permukaan logam, dapat ditunjukkan oleh data kuantitatif distribusi nilai hue sepanjang garis tengah pemukaan TLC untuk setiap citra, seperti pada gambar 8 .

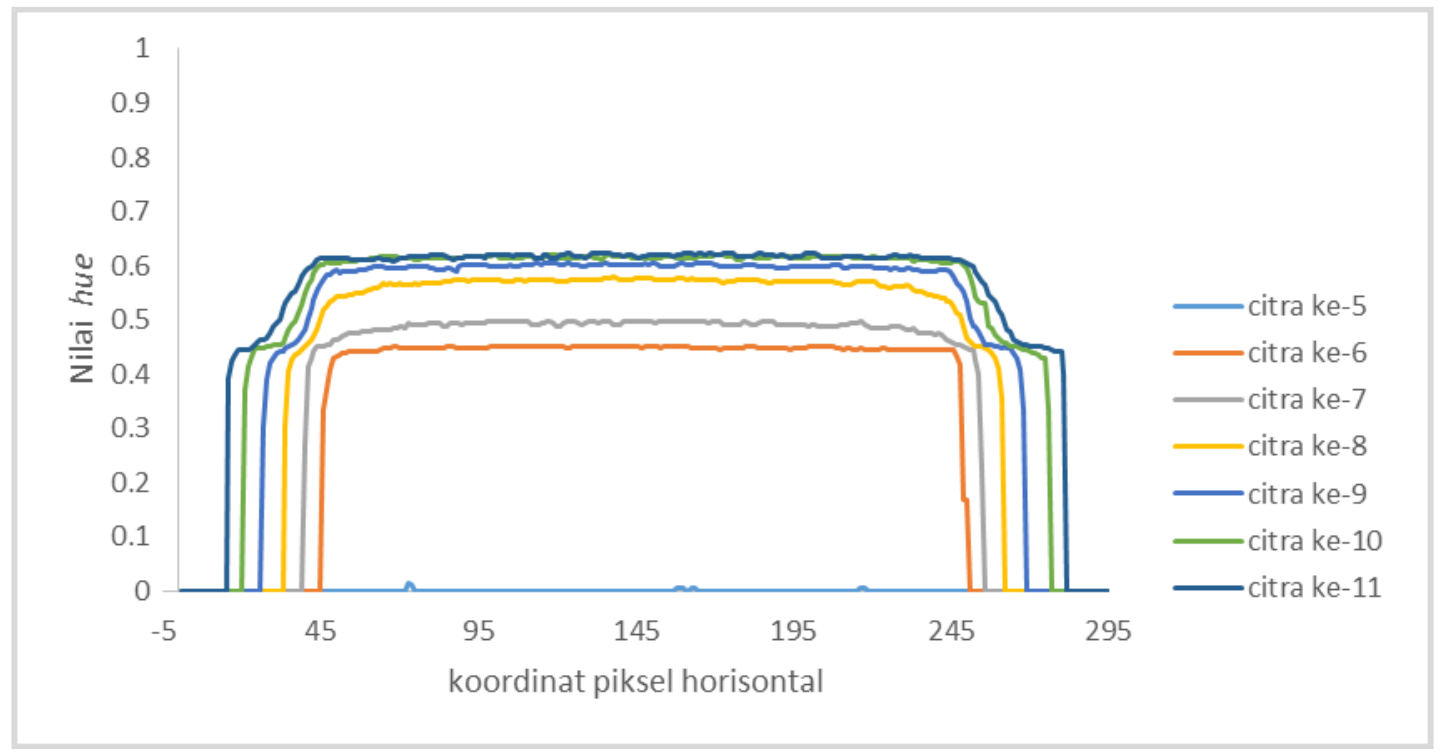

Gambar 8. (color online) Distribusi nilai hue sepanjang garis tengah citra permukaan $T L C$ y ang mengalami kontak dengan permukaan logam kuningan

Berdasarkan grafik gambar 8, tampak bahwa nilai hue sepanjang garis tengah lingkaran pada permukaan $T L C$ menunjukkan nilai yang cukup merata di bagian tengahnya (lingkaran dalam), namun semakin berkurang di tepinya (tepi kanan dan kiri). Pola untuk logam kuningan dapat teramati mulai citra ke 5, sesuai dengan kenaikan temperatur logam. Citra ke-11 menunjukkan temperatur yang paling tinggi dari citra lainnya. Melalui gambar 8 juga dapat ditunjukkan, bahwa semakin tinggi kenaikan temperatur permukaan logam, maka nilai 
hue sepanjang garis tengah citra permukaan TLC akan semakin tinggi, sesuai dengan hasil pada gambar 7 .

\section{KESIMPULAN}

TLC dapat diaplikasikan untuk mengamati peristiwa perpindahan kalor pada permukaan logam kuningan, dengan menerapkan metode pengolahan citra, dan melakukan analisis kuantitatif berdasarkan nilai hue dari citra $H S V$ permukaan TLC. Seiring dengan meningkatnya temperatur permukaan logam, nilai mean hue akan meningkat. Nilai hue cukup merata di bagian tengahnya (lingkaran dalam) namun semakin berkurang di tepinya (tepi kanan dan kiri), yang menunjukkan semakin jauh dari tepi permukaan logam maka energi kalornya semakin berkurang, karena terjadi perpindahan kalor pada tepi permukaan logam ke udara di sekitarnya.

\section{UCAPAN TERIMAKASIH}

Penulis mengucapkan terimakasih kepada LPPM Universitas Katolik Parahyangan Bandung, atas dukungan dana penelitian dan kepada Dr Aloysius Rusli atas pembinaannya.

\section{DAFTAR PUSTAKA}

1 Yang, Deng-Ke \& Wu, Shin-Tson. 2006. Fundamentals of Liquid Crystal Devices. John Wiley\&Son Ltd.

2 Hallcrest. 1991. Handbook of Thermochromic Liquid Crystal. Glenview, IL, Hallcrest.

3 Bharara, Manish. 2007. Liquid Crystal Thermography in Neuropathic Assesment of Diabetic Foot, $\mathrm{PhD}$ Thesis, Bournemouth University.

4 Suryantari \& Flaviana. 2015. Linearization of Hue Value on the Surface of Thermochromic Liquid Crystal with Variation of Temperature. Indonesian Journal of Applied Physics. Volume: 05(1), page 84-91.

5 J.A. Stasiek and T.A. Kowalewski. 2002. Thermochromic liquid crystals applied for heat transfer research. Opto-Electronic Review 10(1), 1-10.

6 Gonzales, R.C., Woods, R.E. 2002. Digital Image Processing, 2ed, Prentice Hall.

7 Zemansky, W. Mark and Dittman, H Richard. 1997. Heat and Thermodynamics. $7^{\text {th }}$ ed. McGraw-Hill, Inc. 